$$
\begin{aligned}
& \text { مهار تكثير رده سلولى سرطان مرى ( KYSE-30) توسط متابوليتهاى ثانويه باكترى هاى } \\
& \text { اندوفيت افلرا }
\end{aligned}
$$

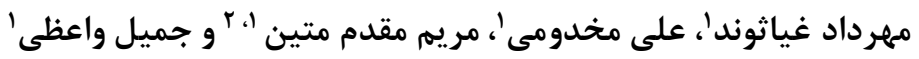

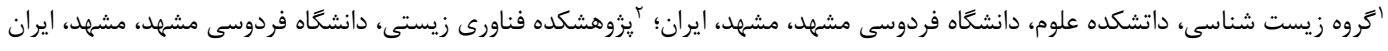

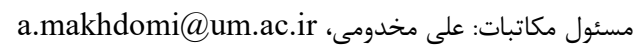

ج جكيده. با توجه به افزايش نرخ بروز سرطان مرى در برخى كشورهاى آسيايى از جمله مناطق شمال و شمالشرق ايران، شناسايى تركيبات ضدسرطانى جديد

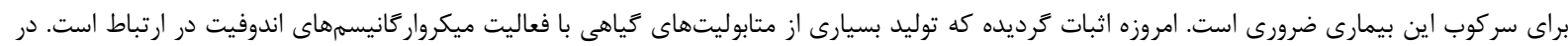

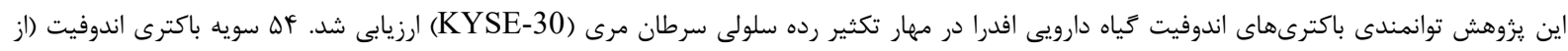

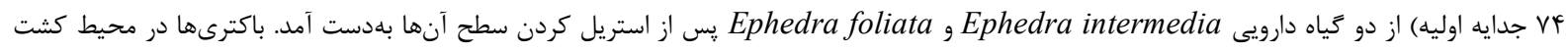

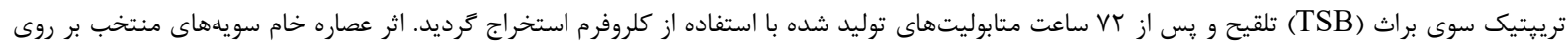

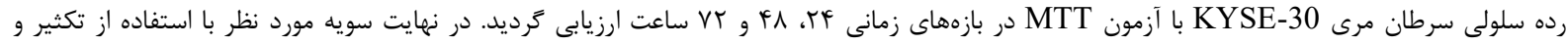

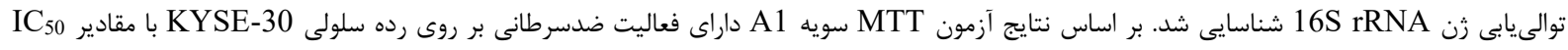

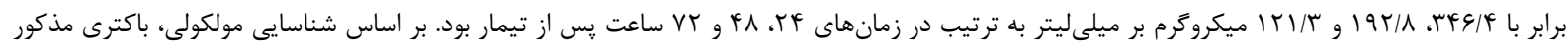

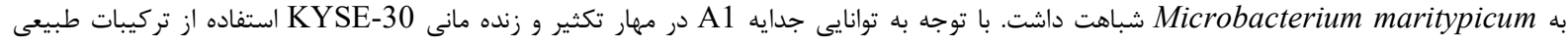

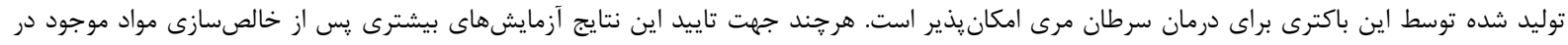

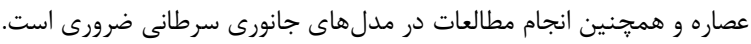
وازههاى كليدى. اكتينوباكتر، سميت سلولى، كياهان دارويى، ميكروباكتريوم، همزيستى

\title{
Inhibition of esophageal cancer cell line (KYSE-30) proliferation using secondary metabolites of Ephedra endophyte bacteria
}

\author{
Mehrdad Ghiasvand ${ }^{1}$, Ali Makhdoumi ${ }^{1}$, Maryam Moghaddam Matin ${ }^{1,2}$ \& Jamil Vaezi ${ }^{1}$ \\ ${ }^{1}$ Department of biology, Faculty of Science, Ferdowsi University of Mashhad, Mashhad, Iran; ${ }^{2}$ Institute of \\ Biotechnology, Ferdowsi University of Mashhad, Mashhad, Iran \\ Correspondent author: Ali Makhdoumi, a.makhdomi@um.ac.ir
}

\begin{abstract}
Regarding the rising rate of esophageal cancer in some parts of Asia, including northern and northeastern regions of Iran, the identification of new anti-cancer compounds is essential to combat the disease. The relation between some plants metabolites and these endophytic microorganisms are well characterized. In the current study, the potentials of Ephedra endophyte bacteria for the inhibition of esophageal cancer cell line (KYSE-30) proliferation were investigated. A total of 54 endophyte bacteria (out of 70) were obtained from the sterilized surfaces of two medicinal plants, i.e., Ephedra intermedia and Ephedra foliata. Bacterial strains were then cultured in Tryptic soy broth (TSB) medium and, after $72 \mathrm{~h}$ incubation, the produced secondary metabolites were extracted by chloroform. Anticancer effects of secondary metabolites from theses bacteria on esophageal cancer cell line KYSE-30 were evaluated after 24, 48 and $72 \mathrm{~h}$ by MTT method. MTT assay results showed that only strain A1 had a cytotoxic effect on KYSE-30 cells. The $\mathrm{IC}_{50}$ amounts of this strain against KYSE-30 cell lines were equaled $(\mu \mathrm{g} / \mathrm{ml})$ to $346.4,192.8$ and 121.3 after 24,48 , and 72 hours, respectively. The molecular identification of strain A1 revealed that Microbacterium maritypicum (99.8\%
\end{abstract}


similarity) was the closest identified taxon to the strain studied. According to the promising ability of strain A1 to inhibit the growth of KYSE-30 cell line, the use of natural compounds produced by this bacterium to treat esophageal cancer was found to be applicable. However, more experiments are needed to confirm these results after purifying the ingredients, as well as conducting studies in animal cancer models.

Key words. Actinobacter, cytotoxic effect, medicinal plant, Microbacterium, symbiosis

است (Yang et al., 2018). بلعلاوه خطر انقراض، گياهان دارويى يك منطقه را به دنبال برداشتهاى بىرويه تهديد

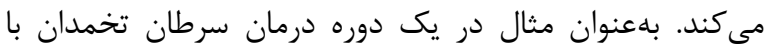

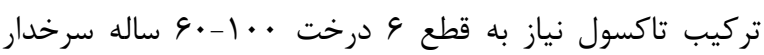

است (Nasiri-Madiseh et al., 2010).

اندوفيتها ميكروار گانيسمهاى ساكن در بافتهاى مختلف زياه

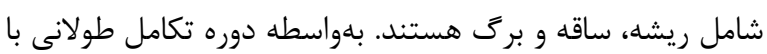

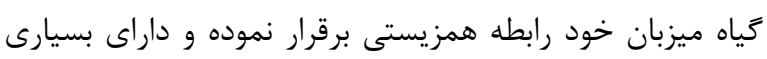

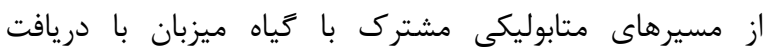

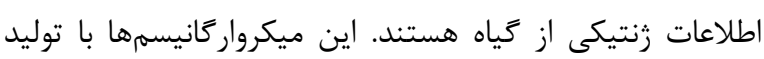
تركيبات فعال زيستى براى مقابله زياه با ميكرواركانيسمهاى

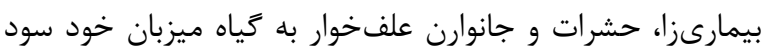

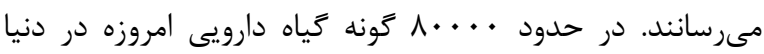
شناخته شده است. اين گياهان هركدام مى توانند ميزبان جندين

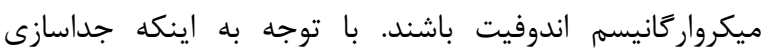

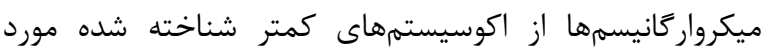
توجه است، ارزيابى توانايى اندوفيتها در توليد متابوليتهاى

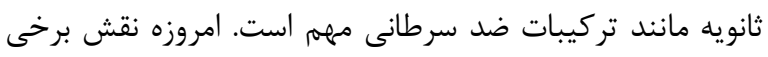

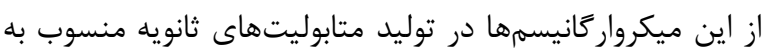

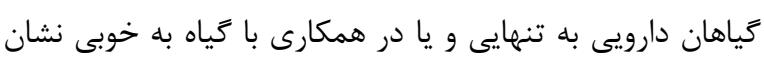

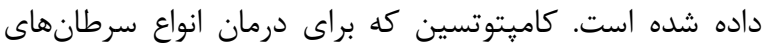

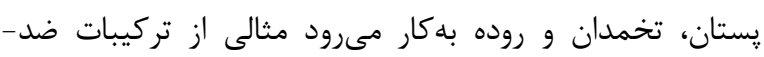

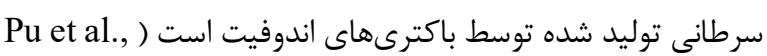
(2015; Seca \& Pinto, 2018 افدرا از زياهان يرسابقه در طب سنتى و از جمله فلور طبيعى

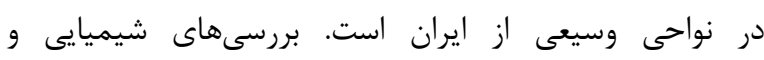
فارماكولوزى مختلفى بر روى اين گياه صورت گرفته است. در اين

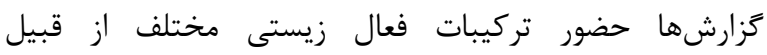

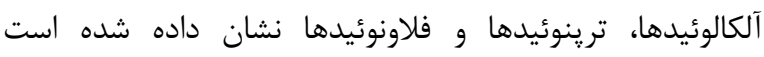

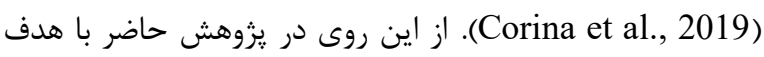

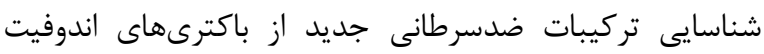

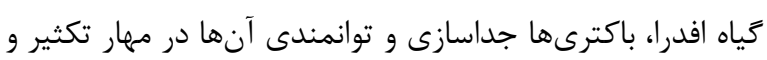
زندهمانى سلولهاى رده سلولى سرطان مرى

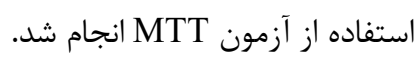

سرطان مرى با توجه به نرخ مرگومير بالا، امروزه يكى از

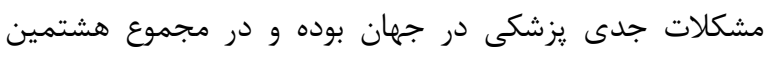

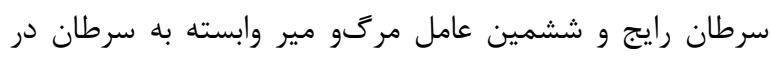
كل دنيا محسوب مىشود (Smyth et al., 2017). اين سرطان

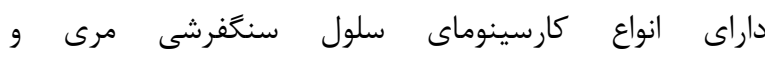
آدنوكارسينوماى مرى است كه خصوصيات و علل بروز متفاوتى دارند كه مىتواند به سبك زندگى، شرايط محيطى و واستعداد استو

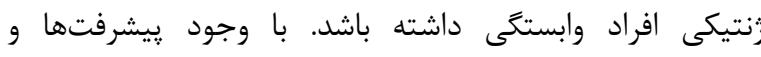

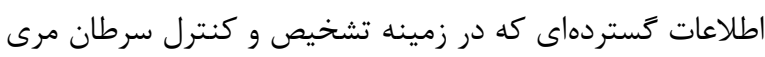

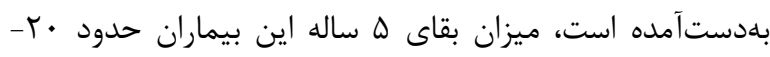

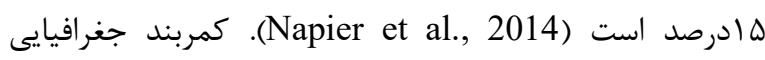
سرطانهاى مرى و معده از كشور جين تا نواحى شمالى ايران امتداد يافته است، بهطورى كه در شمال كشور ايران و در در استان

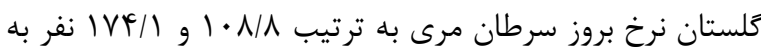

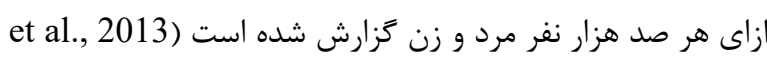
د. Aghababaei-Ziarati

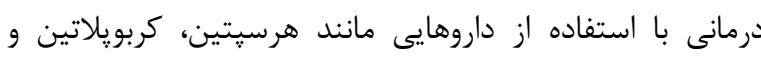

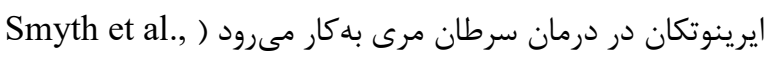

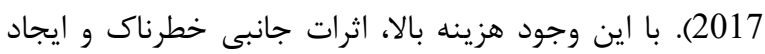

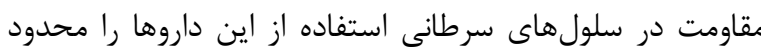

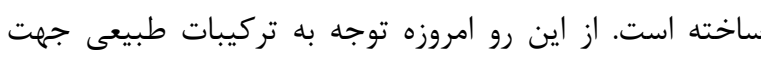
كاربرد در شيمىدرمانى كسترش يافته است.

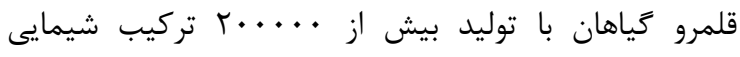

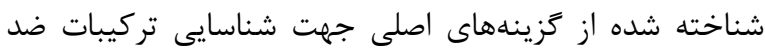

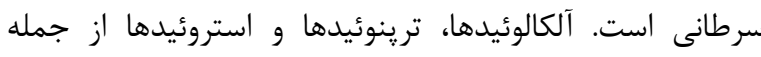
مهمترين تركيبات فعال زيستى جدا شده از زياهان دارويى

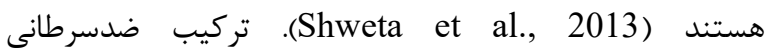
هوموهارينگتونين توسط گياه سرخدار آلو ( Cephalotaxus

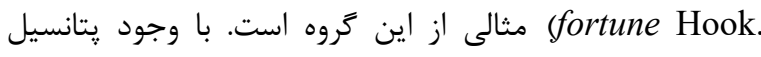
بالاى گياهان دارويى در توليد تركيبات ضدسرطانى جديد،

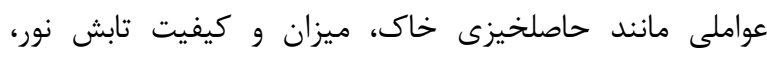

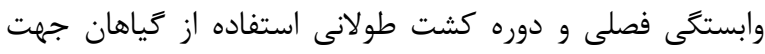
توليد تركيبات فعال زيستى را با محدوديتهايى همراه ساخته 
با دماى • r درجه سانتى براد به منظور تقطير حلال در شرايط خلأ

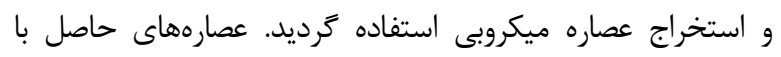

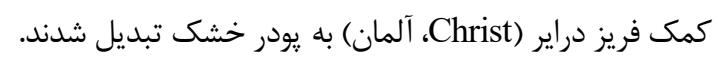

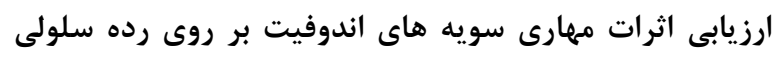
سرطان مرى (KYSE-30) به منظور ارزيابى اثرات ضد سرطانى سويههاى اندوفيت از رده سلولى سرطانى مرى KYSE-30 استفاده كرديد.

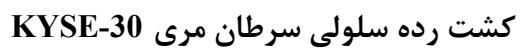

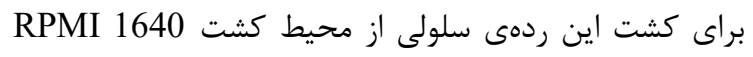

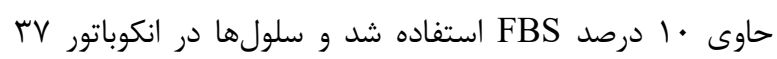

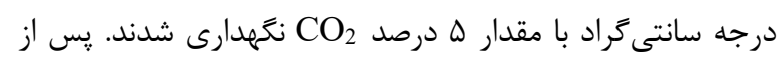

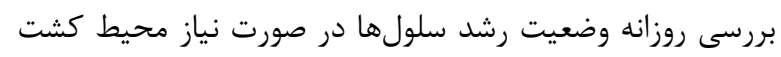

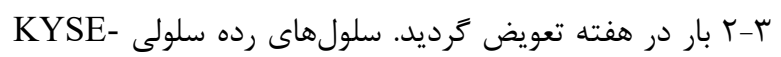

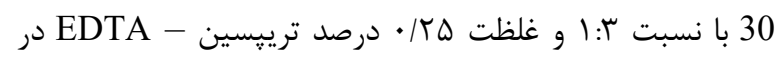
يك ميلىمولار پاساز داده شدند (r) (Shi et al., 2018). بررسى اثر ضد سرطانى متابوليت اندوفيت ها

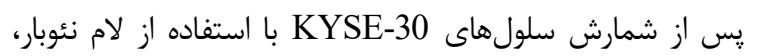

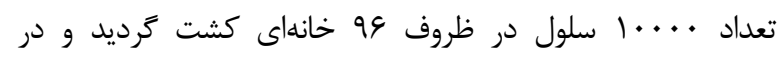

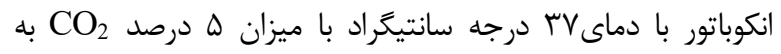

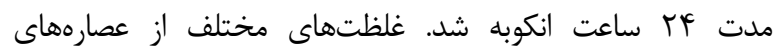

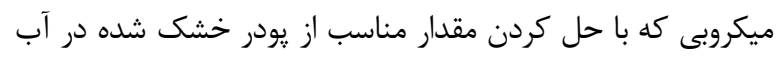

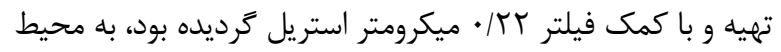
كشت سلول هاى KYSE-30 افزوده شد. از تيمار آب مقطر استريل

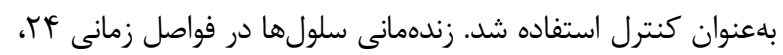

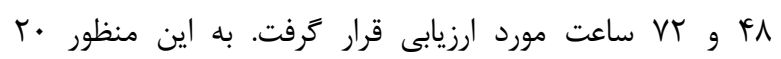

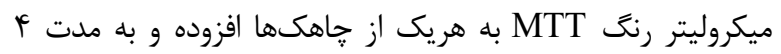

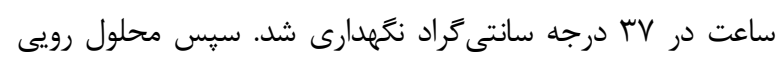

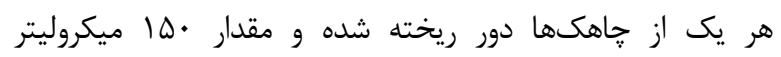
DMSO به آنها افزوده شد. در نهايت با استفاده از دستكاه الايزا

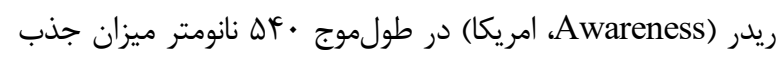

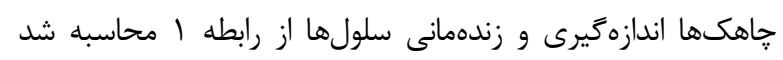
.(Maheswarappa et al., 2013)

$$
\begin{aligned}
& \text { رابطه ا: } 100 \\
& \text { AT } \\
& \text { AC ميزان جذب كنترل حلال = AC }
\end{aligned}
$$

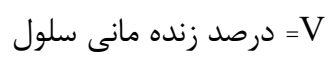

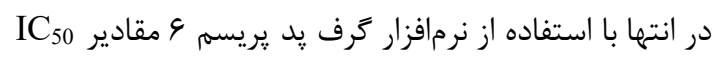

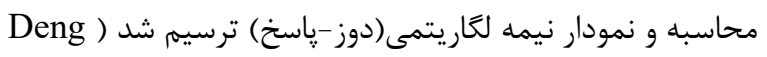

.(et al., 2013

$$
\text { جمع آورى كياه افدرا ورا }
$$

و عياهان دارويى أوري افراه E. foliata Boiss. ex C.A.Mey. N: 360731.9-E: روستاى عارفى با موقعيت جغرافيايى 593148.1 جمعآورى و توسط متخصصان هرباريوم دانشكده علوم دانشكاه فردوسى مشهد تعيين تونه شدند (شكل () ). شماره

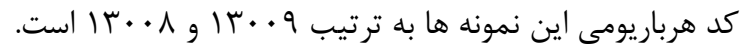

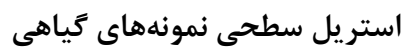

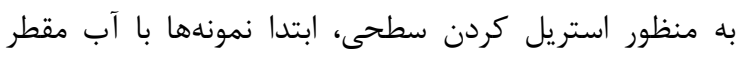

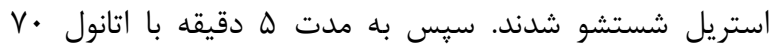

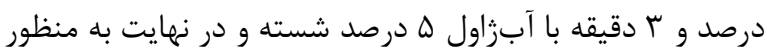

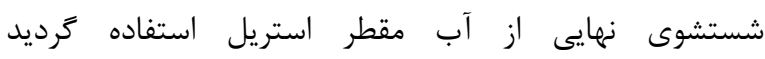

.(Preveena \& Bhore, 2013)

آمادهسازى نمونههاى كياهى در زير هود ميكروبى (زال تجهيز، ايران) با استفاده از تيغ نمادي

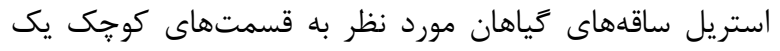

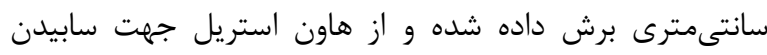

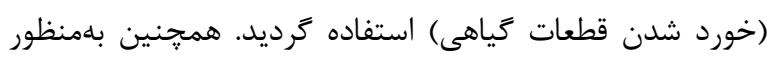

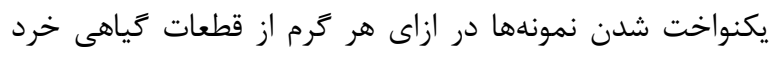

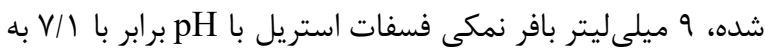

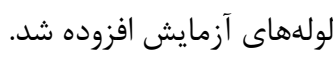
جداسازى باكترىهاى اندوفيت يس از تهيه سرى رقتهاى مختلف از بافت كياهى يكنواخت أندوفيت

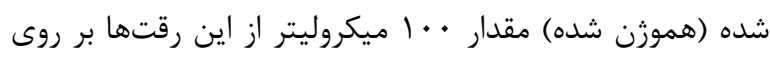

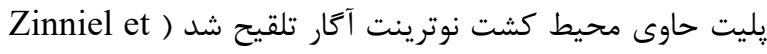

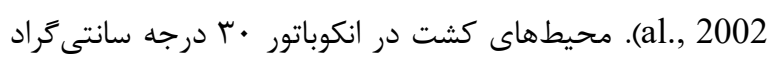

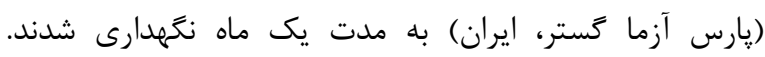

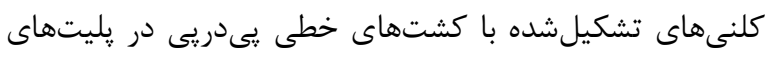

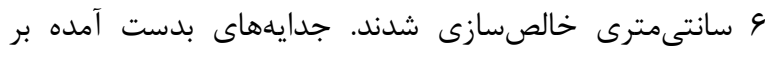

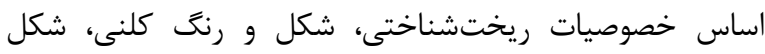

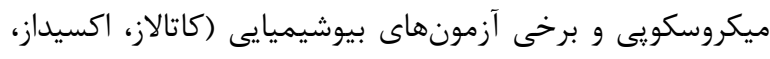

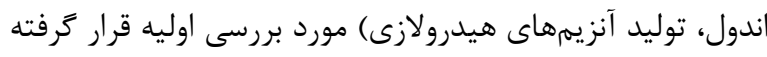

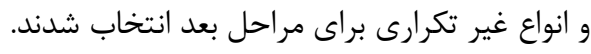

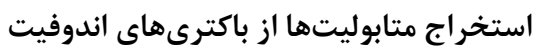

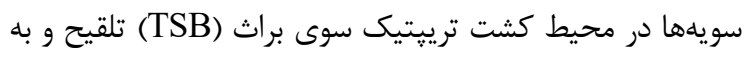

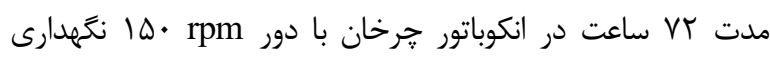

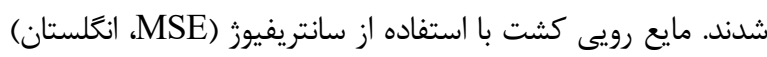

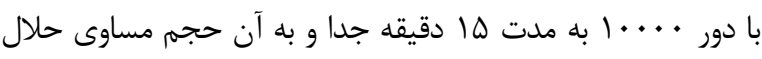
كلروفرم افزوده شد. در نهايت از دستخاه روتارى (Labtech، امريكا) 

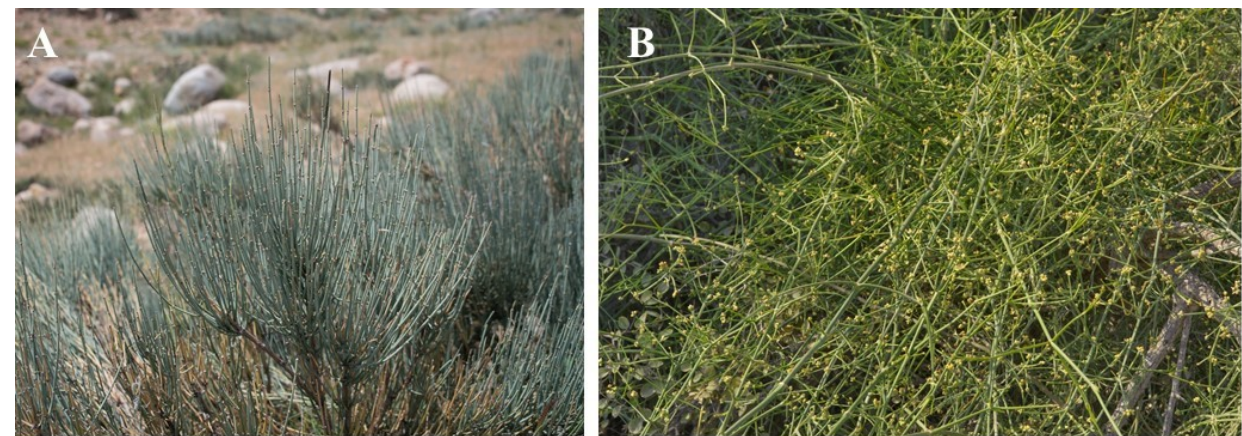

شكل ا- گياهان دارويى A. افدرا اينترمديا و B. افدرا فولياتا جمع آورى شده از استان خراسان رضوى- روستاى عارفى. عكس: على اصغر بصيرى צوب ا.

Figure 1. Medicinal plants studied, A. Ephedra intermedia and B. Ephedra foliate collected from Khorassan Razavi Province, Iran -Arefi village. Photo by A.A. Basiri 2017.

يس از كشت سويههاى منتخب، متابوليتهاى ثانويه توليده شده با كمك كلروفرم استخراج و خشك گرديد. اثر غلظتهاى مختلف از عصارههاى ميكروبى بر روى رده سلولى با آزمون نشان داد كه تنها جدايه A1 MTT سلولهاى رده سلولى سرطان مرى KYSE-30 در بازههاى

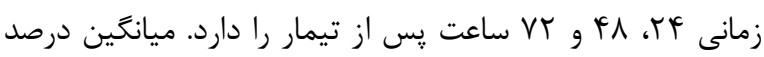

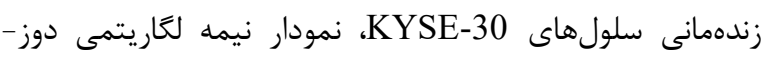
ياسخ و مقادير IC50 در سه بازه زمانى به ترتيب در جدول Iا، شكل أ و جدول r نشان داده شده است. اثرات ضدسرطانى سويه A1 وابسته به غلظت بوده و و با افزايش غلظت و همينطور زمان مجاورت تركيب با سلول افزايش يافته است. افزايش زمان به VY ساعت بهطور معنى دارى اثرات سميت

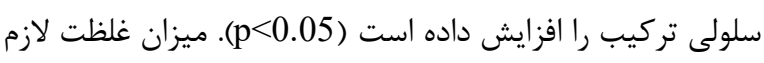
براى قابليت مهار كنندگى • له درصدى عصاره خام سويه A1 نيز با افزايش زمان كاهش يافته بهطورى كه اين ميزان در زمانهاى  ميكروگرم در ميلىليتر محاسبه شد.

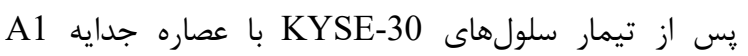
تغييرات ريختشناختى اين سلولها با استفاده از ميكروسكوب

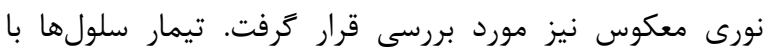
عصاره باكترى اندوفيت A1 باعث تغيير شكل آنها از حالت طبيعى و تبديل آنها به سلولهاى كروى و گرانوله گرديد (شكل

\section{A1 Aناسايى مولكولى سويه} تعيين توالى محصول واكنش تكثير ثن 16S rRNA نشان داد كه جدايه A1 به باكترى Microbacterium maritypicum شباهت دارد. ارتباط فيلوزنتيكى اين سويه با باكترىهاى شناخته شده نشان داد اين باكترى به كروه اكتينوباكترها تعلق دارد (شكل ؟ ع).

\section{شناسايى مولكولى باكترىهاى اندوفيت}

شناسايى سويه منتخب با بيشترين سميت سلولى بائ با روش مولكولى بر مبناى توالىيابى زن 16S rRNA انجام شد. زنومى با كيت استخراج DNA (سينازن، ايران) استخراج گرديد. تكثير زن 16S rRNA با استفاده از آغازگرهاى عمومى 27F و و PCR در واكنش زنجيرهاى يليمراز انجام و محصول 1492R

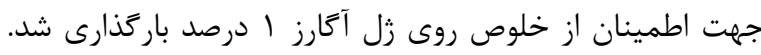

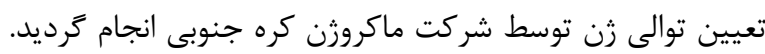

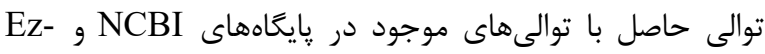
Biocloud شناختهشده با استفاده از الگوى Neighbour-joining و و نرمافزار معا و ترسيم گرديد (Kumar et al., 2016).

\section{نتنابج}

\section{جداسازى و خالصسازى اندوفيتها}

در اين يثزوهش تعداد • V كلنى باكترى اندوفيت از خياه افدرا

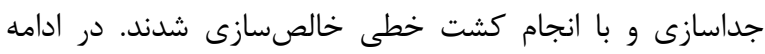

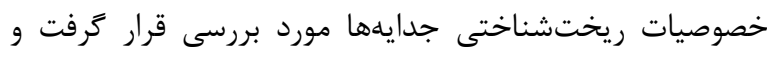
تعداد هاه باكترى كه از لحاظ شكل ميكروسكويى و شكل كلنى متفاوت بودند براى ادامه آزمايشها انتخاب شدند. نتايج اين

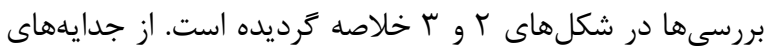

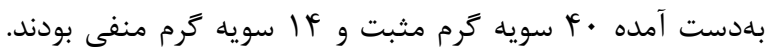

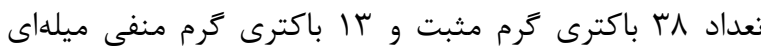

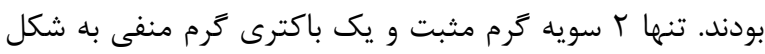
كو كسى مشاهده شدند.

بررسى توانمندى جدايهها در مهار رشد سلولهاى سرطانى KYSE-30 


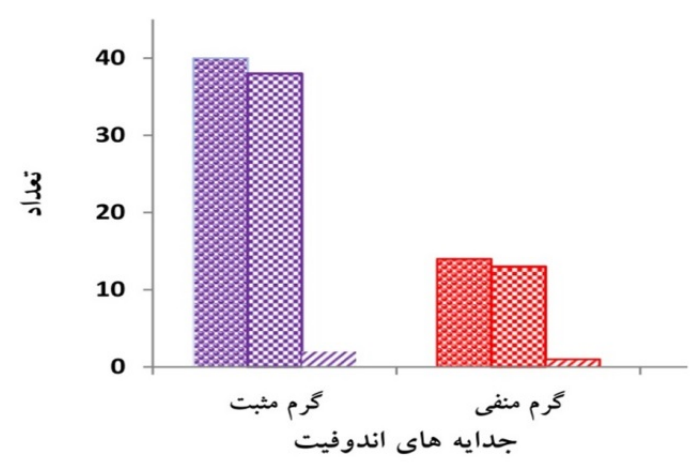

شكل r - ويزگى هاى ريختشناختى جدايههاى بهدست آمده از كياه افدرا. دايره: كل سويهها، مربع: باكترىهاى ميله ای، هاشور: باكترىهاى كروى.

Figure 2. The morphological features of the isolates obtained from the Ephedra plants. Circle: whole strains, square: rod bacteria, diagonal: spherical bacteria
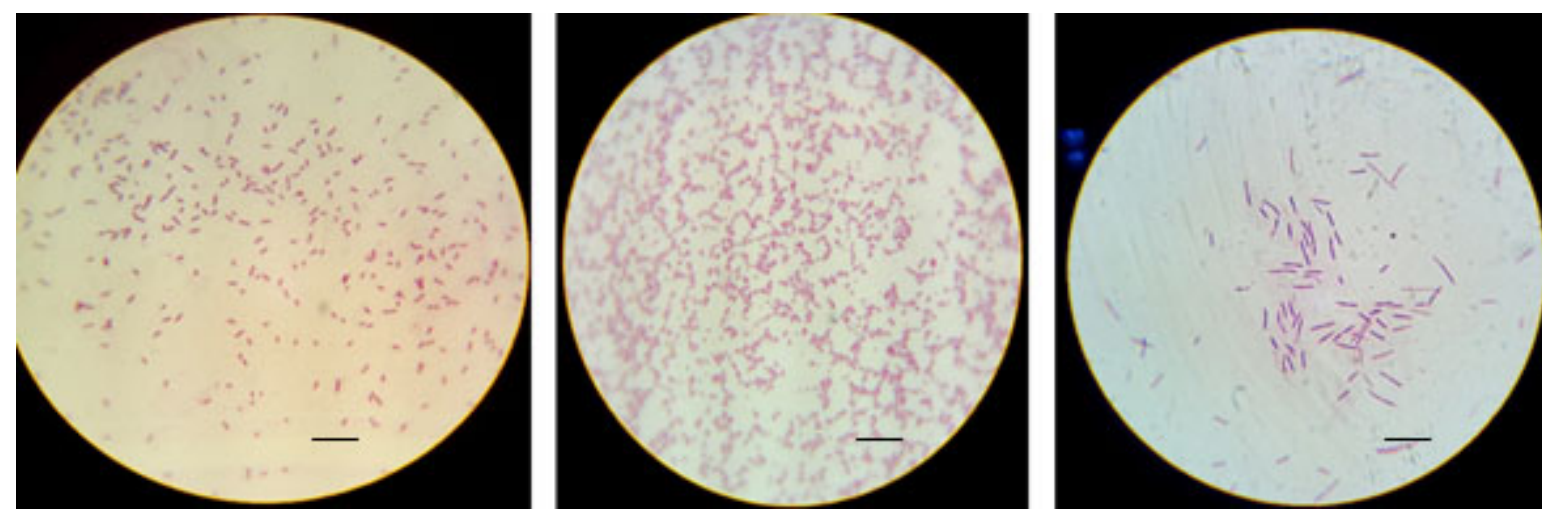

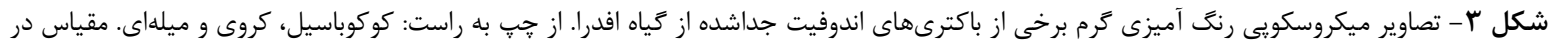

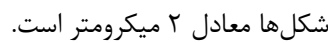

Figure 3. Gram-staining microscopic images of some endophytic bacteria isolated from the Ephedra plants. From left to right: coccobacillus, coccus and bacillus. Bars, $2 \mu \mathrm{m}$.

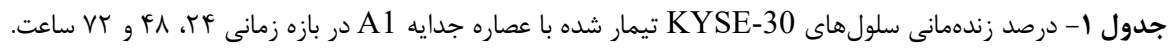

Table 1. Viability of KYSE-30 cells treated by strain A1 extract after 24, 48 and 72 hours.

\begin{tabular}{|c|c|c|c|c|c|c|c|}
\hline$r I / r \Delta$ & GT/D & ITS & $r \Delta$. & $\Delta .$. & $1 \ldots$ & $r . .$. & غلظت ( \\
\hline $9 \Delta / 1$ & $\Delta r / r$ & $\Delta T / G$ & $4 q / 1$ & $F N / \Lambda$ & $F \Delta / \Delta$ & $F r / \Lambda$ & Flf ساعت TF \\
\hline $9 \cdot / 4$ & $01 \%$ & $\boldsymbol{F} / \boldsymbol{F}^{\mathrm{s}}$ & $F V / T$ & $\varphi \Delta / \Delta$ & FT/T & & f^ ساعت \\
\hline$\Delta F / q$ & $\forall N / V$ & $F F / \Lambda$ & $F I / V$ & $r \cdot 19$ & $\mathrm{rN} /$. & $r r / F$ & ساعت VY \\
\hline
\end{tabular}




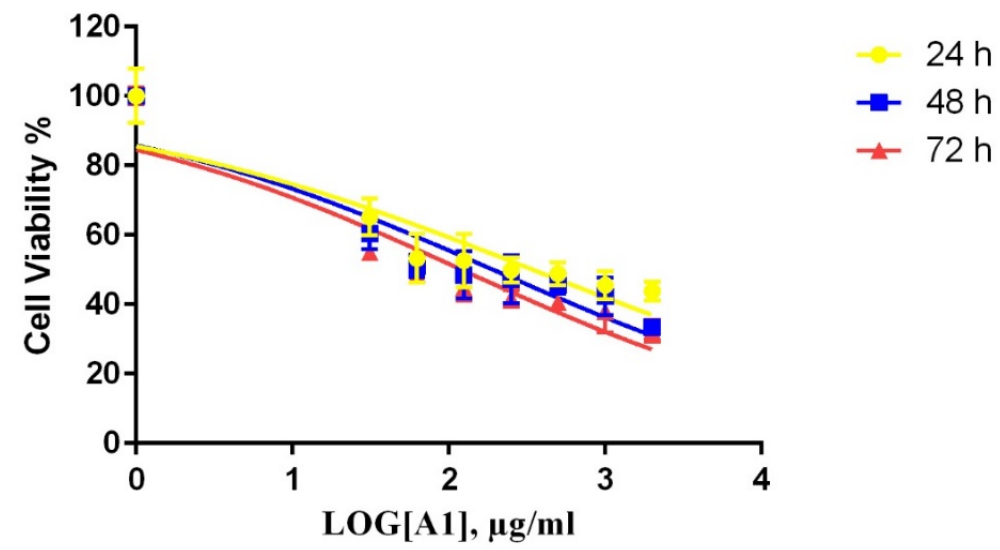

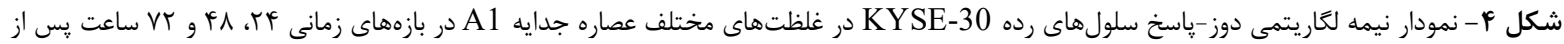

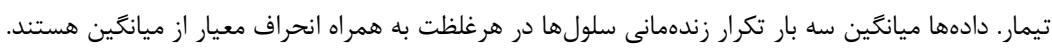

Figure 4. Semi-logarithmic dose-response diagram of KYSE-30 cells in different concentrations of A1 strain extract in the time periods of 24,48 and 72 hours after treatment. Data is an average of three experiments with the standard deviation.
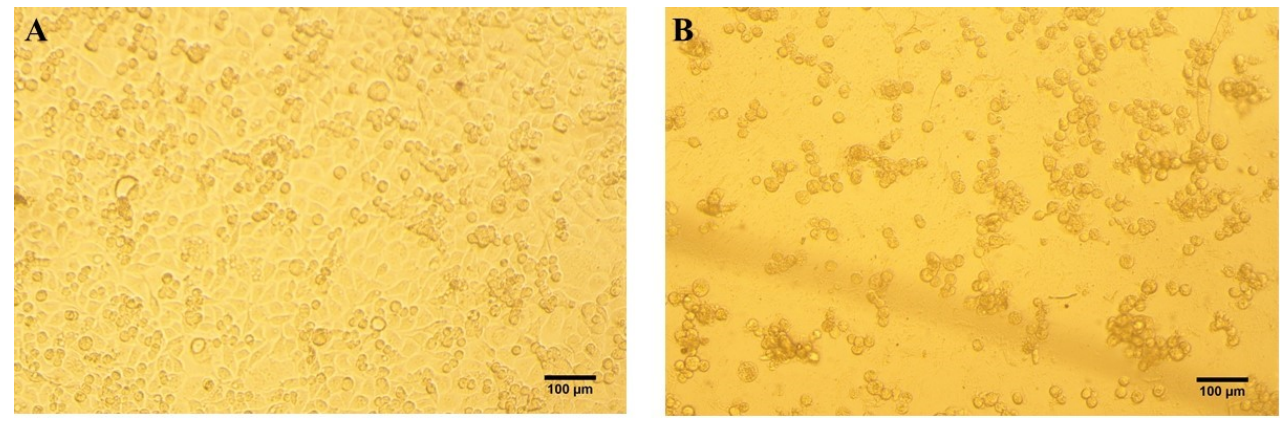

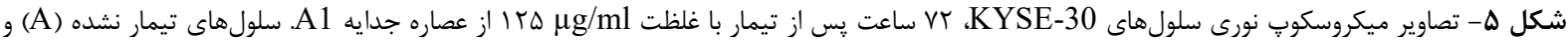

سلولهاى تيمار شده (B).

Figure 5. Light microscopic images of treated KYSE-30 cells with strain A1 extract $(125 \mu \mathrm{g} / \mathrm{ml})$ after $72 \mathrm{~h}$. A: untreated cells B: treated cells.

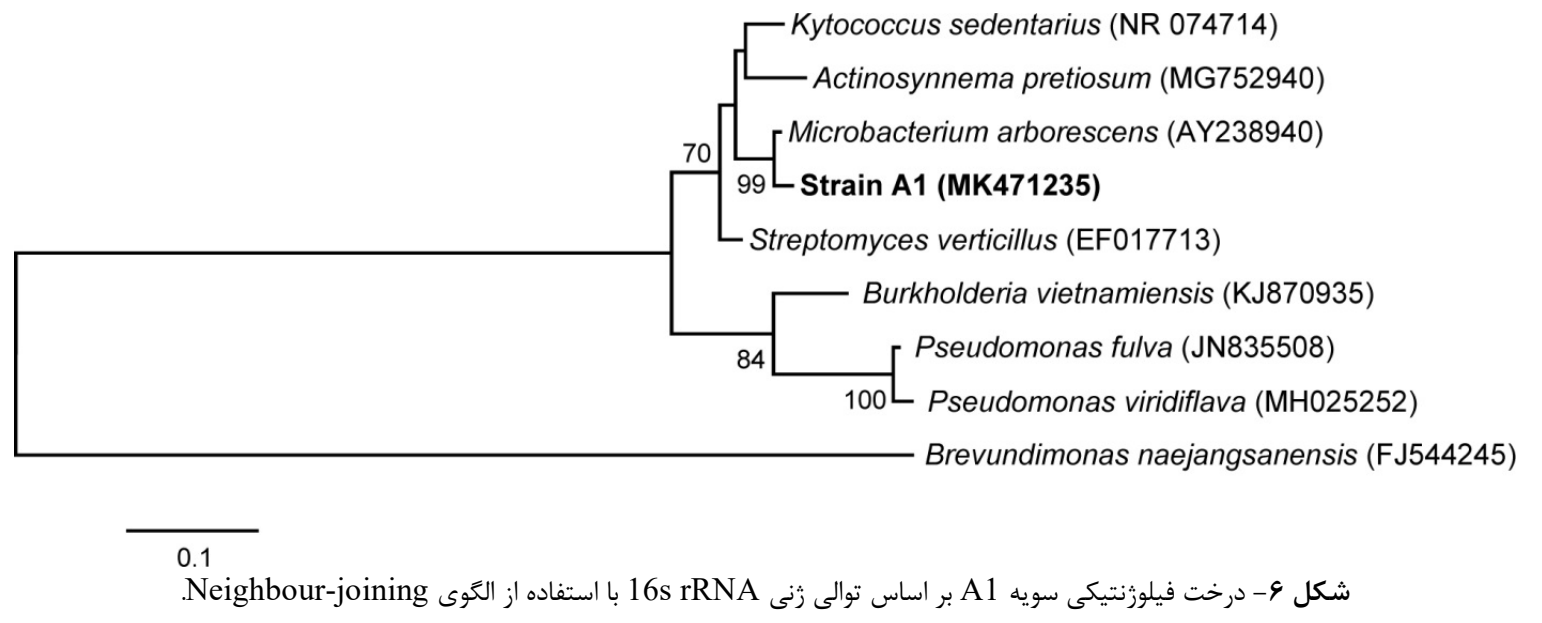

Figure 6. Neighbour-joining phylogenetic tree of strain A1 based on 16S rRNA gene sequence. 
يزوهش حاضر نيز توانايى باكترى اندوفيت كياه افدرا در مهار

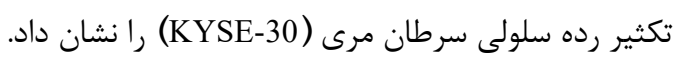

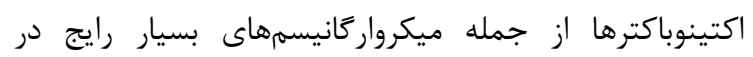

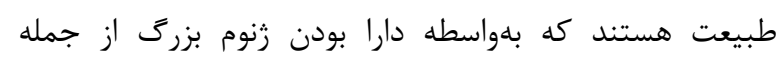

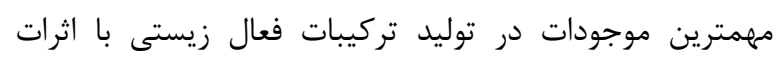

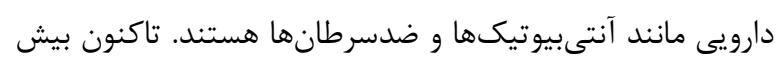

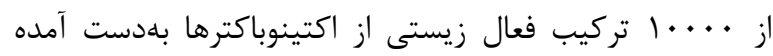

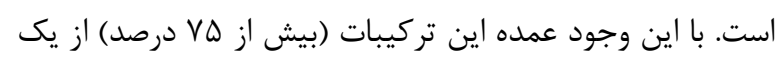

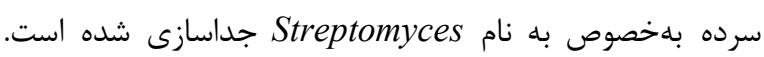

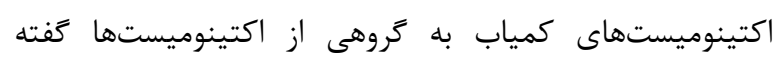

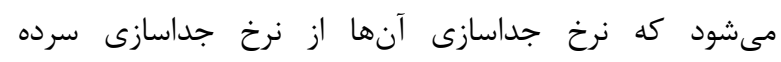
Streptomyces

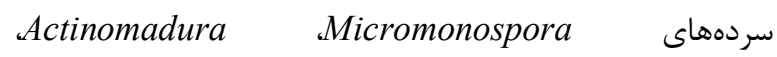
Microbacterium, Amycolatopsis نياز به متابوليتهاى فعال زيستى جديد از يك سو و كاهش

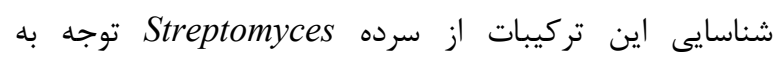

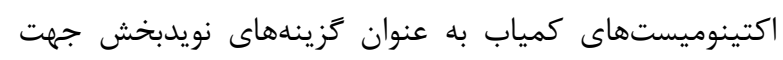

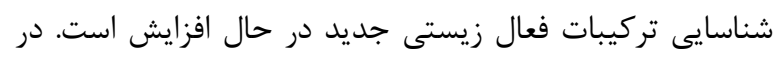
يزوهش حاضر باكترى Microbacterium sp. A1 با فعاليت ضدسرطانى از ساقه كياه دارويى A. intermedia

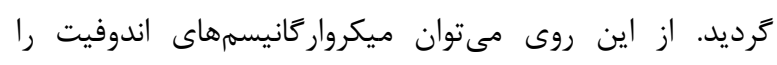

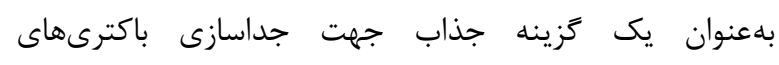
اكتينوميست كمياب بيشنهاد نمود. فعاليت ضدسرطانى باكترىهاى سرده Microbacterium بر بردئن

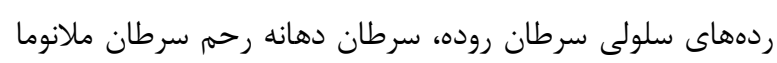
و سرطان يستان كزارش شده است ( Azman et al., 2017

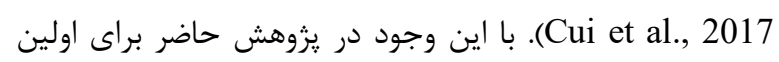
بار اثرات مهاركنندگى تكثير بر روى رده سلولى

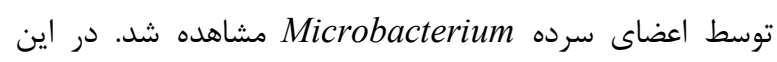

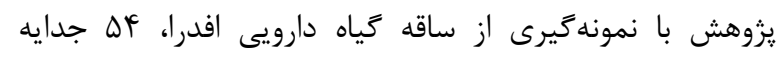

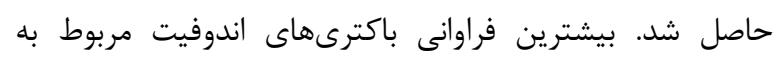

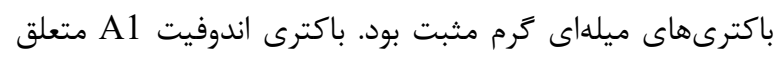

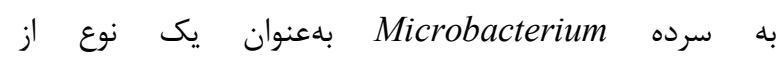
اكتينوميستهاى كمياب توانايى مهار تكثير رده سلولى سرطان

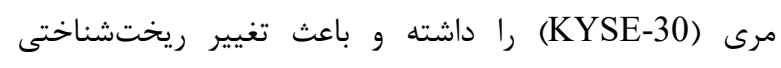

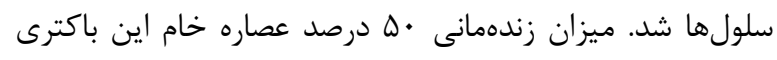

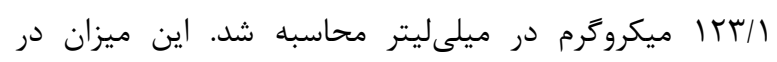

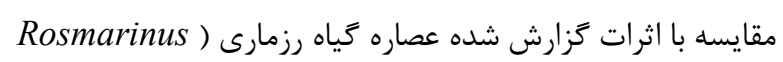

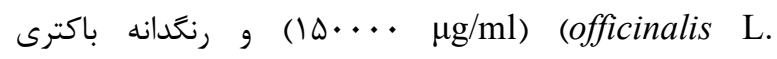

توجه به نقش مهم كياهان دارويى در درمان بسيارى از

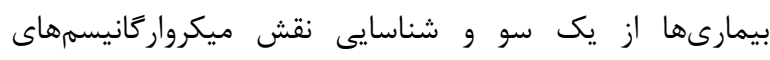

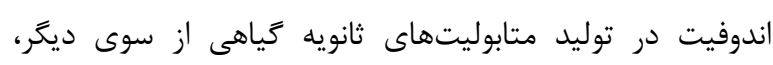

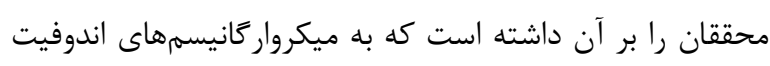

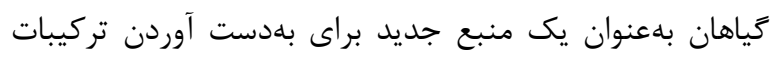

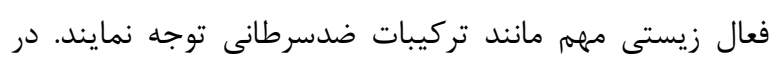

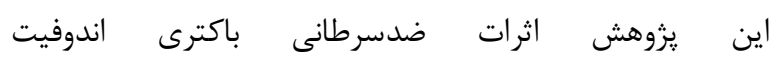
Microbacterium sp. A1

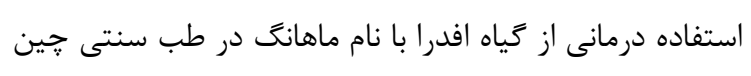

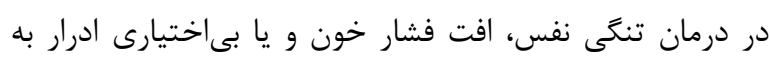

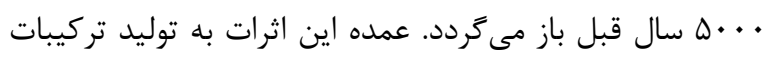

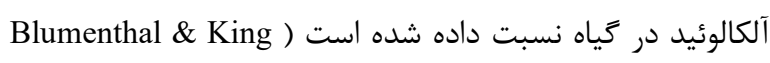

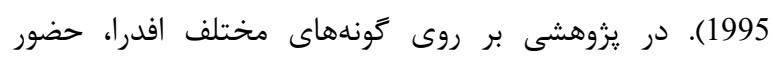

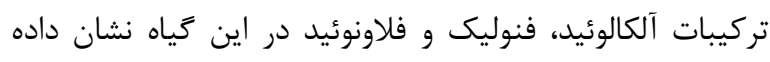

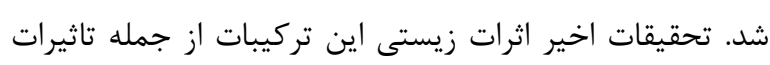

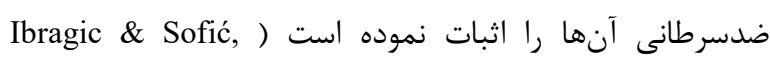

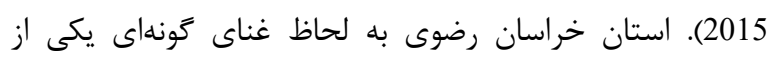
مناطق با تنوع نسبى بالا در كشور است ( Ghahremaninejad et

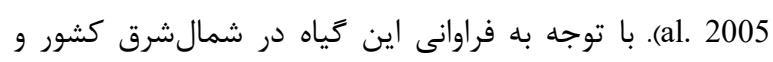

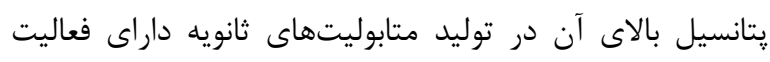

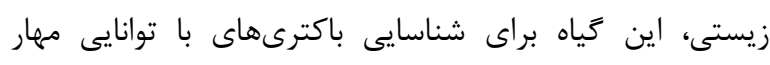
سلول هاى سرطانى انتخاب كرديد.

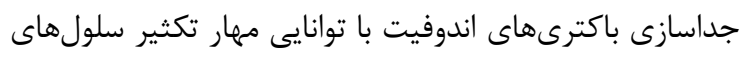

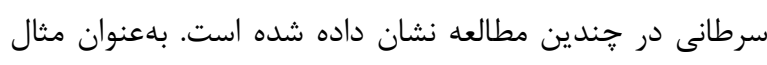

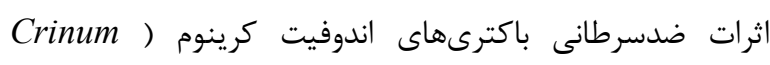
(macowanii Baker

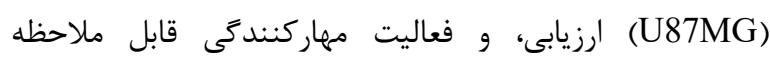

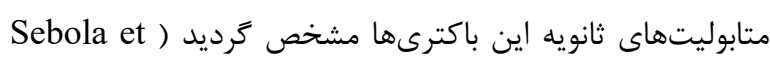

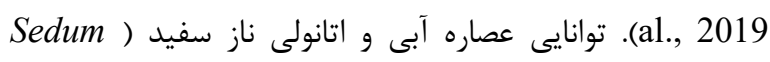
(album L.

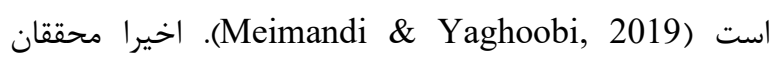
توانايى باكترى اندوفيت LY214 جدا شده از درخت شاد ضوني (Camptotheca acuminata Decne.) ضدسرطانى با ارزش كاميتوتسين كه كاربرد كستردهاى در درمان

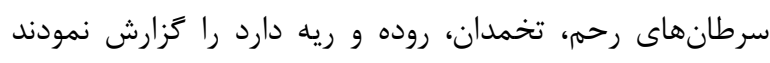

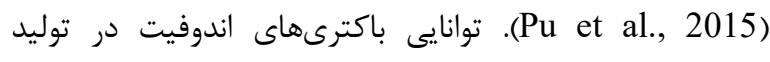
متابوليتهاى فعال زيستى ديخرى مانند ديوسرنين، كَينكلوئيد،

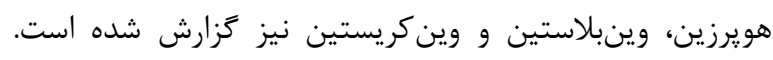




\section{REFERENCES}

Afra, S., Makhdoumi, A., Matin, M.M. \& Feizy, J. 2017. A novel red pigment from marine Arthrobacter sp. G20 with specific anticancer activity. Journal of Applied Microbiology 123: 1228-1236.

Aghababaei-Ziarati, A., Ghorbani, H. \& Hosseinalizadeh, M. 2013. Evaluate the relationship between spatial distribution of esophageal and gastric cancers and soil conditions at the Golestan Province. Journal of Mazandaran University of Medical Sciences 22: 180-193. (In Persian).

Azman, A.S, Othman, I., Fang, C.M., Chan, K.G., Goh, B.H. \& Lee, L.H. 2017. Antibacterial, anticancer and neuroprotective activities of rare Actinobacteria from mangrove forest soils. Indian Journal of Microbiology 57: 177-187.

Blumenthal, M. \& King, P. 1995. Ma Huang: Ancient herb, modern medicine, regulatory dilemma. A review of the botany, chemistry, medicinal uses, safety concerns, and legal status of Ephedra and its alkaloids. HerbalGram 34: 22-26.

Corina, D., Delia, M., Ersilia, A., Claudia, F., Istvan, O., Andrea, B., Minda, D., Proks, M., Buda, V., Hancianu, M., Cioanca, O., Soica, C., Popescu, P. \& Dehelean, C.A. 2019. Phytochemical characterization and evaluation of the antimicrobial, antiproliferative and pro-apoptotic potential of Ephedra alata Decne. Hydroalcoholic extract against the MCF-7 breast cancer cell line. Molecules 24: 13.

Cui, C.H., Kim, D.J., Jung, S.C., Kim, S.C. \& Im, W.T. 2017. Enhanced production of gypenoside LXXV using a novel ginsenoside-transforming $\beta$ glucosidase from ginseng-cultivating soil bacteria and its anti-cancer property. Molecules 22: 844 .

Deng, L., Ren, Z., Jia, Q., Wu, W., Shen, H. \& Wang, Y. 2013. Schedule-dependent antitumor effects of 5fluorouracil combined with sorafenib in hepatocellular carcinoma. BMC Cancer 13: 363.

Ghahremaninejad, F., Joharchi, M.R. \& Vitek, E. 2005. New plant records for Khorassan province, Iran. Annalen des Naturhistorischen Museums in Wien, Serie B 106: 255-293.

Ibragic, S. \& Sofić, E. 2015. Chemical composition of various Ephedra species. Bosnian Journal of Basic Medical Sciences 15: 21-27.

Karimi, N., Rashedi, J., Mahdavi Poor B., Arabi, S., Ghorbani, M., Tahmasebpour, Nahideh. \& Asgharzadeh, M. 2017. Cytotoxic effects of rosemary extract on gastric adenocarcinoma (AGS) and esophageal squamous cell carcinoma (KYSE30) cell lines. Gastroenterology and Hepatology from Bed to Bench 10: 102-107.

Kumar, S., Stecher, G. \& Tamura, K. 2016. MEGA7: molecular evolutionary genetics analysis version 7.0 for bigger datasets. Molecular Biology and Evolution 33: $1870-1874$.

Maheswarappa, G., Kavitha, D., Vijayarani, K. \& Kumanan, K. 2013. Prodigiosin as anticancer drug Produced from bacteria of termite gut. Indian Journal of Basic and Applied Medical Research 1: 257-266.

Meimandi. K. \& Yaghoobi, M.M. 2019. The effect of aqueous and ethanolic extracts of Sedum album L. on بهthrobacter

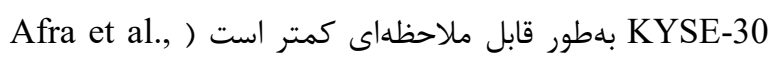

2017; Karimi et al., 2017

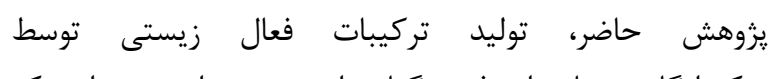

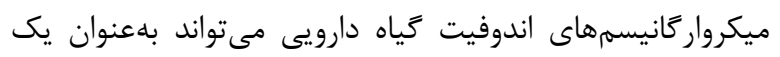

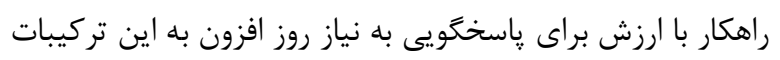

$$
\text { در درمان سرطانها باشد. }
$$

$$
\begin{aligned}
& \text { سياسگَزارى } \\
& \text { اين يزوهش در آزمايشَاه ميكروبيولوزى كاربردى و محيطى و }
\end{aligned}
$$

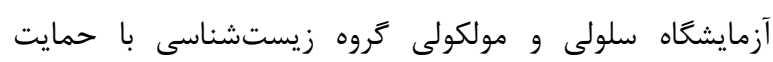

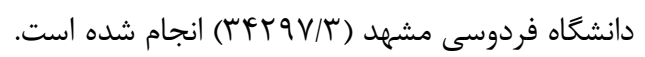


human stomach and breast carcinoma cell lines in vitro. Nova Biologica Reperta 6: 10-19. (In Persian).

Napier, K.J., Scheerer, M. \& Misra, S. 2014. Esophageal cancer: A review of epidemiology, pathogenesis, staging workup and treatment modalities. World Journal of Gastrointestinal Oncology 6: 112-120.

Nasiri-Madiseh, Z., Mofid, M., Ebrahimi, M., KhyamNekouee, S.M. \& Khosravi-Ahahli, M. 2010. Isolation of taxol-producing endophytes fungi from Iranian yew (Taxus baccata L.). Journal of Shahrekord University of Medical Sciences 11: 101106. (In Persian).

Preveena, J. \& Bhore, S.J. 2013. Identification of bacterial endophytes associated with traditional medicinal plant Tridax procumbens Linn. Ancient Science of Life 32: 173-177.

Pu, X., Chen, F., Yang, Y., Qu, X., Zhang, G. \& Luo, Y. 2015. Isolation and characterization of Paenibacillus polymyxa LY214, a camptothecinproducing endophytic bacterium from Camptotheca acuminata. Journal of Industrial Microbiology and Biotechnology 42: 1197-1202.

Sebola, T.E., Uche-Okereafor, N.C., Tapfuma, K.I., Mekuto, L., Green, E. \& Mavumengwana, V. 2019. Evaluating antibacterial and anticancer activity of crude extracts of bacterial endophytes from Crinum macowanii Baker bulbs. Microbiology Open 8: 914.

Seca, A. \& Pinto, D. 2018. Plant secondary metabolites as anticancer agents: Successes in clinical trials and therapeutic application. International Journal of Molecular Sciences 19: 263.

Shi, Y., Liu, X., Fredimoses, M., Song, M., Chen, H., Liu, K., Lee, MH. \& Dong, Z. 2018. FGFR2 regulation by picrasidine $\mathrm{Q}$ inhibits the cell growth and induces apoptosis in esophageal squamous cell carcinoma. Journal of Cellular Biochemistry 119: 2231-2239.

Shweta, S., Bindu, J.H., Raghu, J., Suma, H., Manjunatha, B., Kumara, P.M., Ravikanth, G., Nataraja, K.N., Ganeshaiah, K.N. \& Shaanker, R.U. 2013. Isolation of endophytic bacteria producing the anti-cancer alkaloid camptothecine from Miquelia dentata Bedd. (Icacinaceae). Phytomedicine 20: 913 917.

Smyth, E.C., Lagergren, J., Fitzgerald, R.C., Lordick, F., Shah, M.A., Lagergren, P. \& Cunninghamet, D. 2017. Oesophageal cancer. Nature Reviews Disease Primers 3: 17048 .

Yang, L., Wen, K.S., Ruan, X., Zhao, Y.X., Wei, F. \& Wang, Q. 2018. Response of plant secondary metabolites to environmental factors. Molecules 23: 762.

Zinniel, D.K., Lambrecht, P., Harris, N.B., Feng, Z., Kuczmarski, D. \& Higley, P., Ishimaru, C.A., Arunakumari, A., Barletta, R.G. Vidaver, A.K. 2002. Isolation and characterization of endophytic colonizing bacteria from agronomic crops and prairie plants. Applied and Environmental Microbiology 68: 2198-2208.

How to cite this article:

Ghiasvand, M., Makhdoumi, A., Moghaddam Matin, M. \& Vaezi, J. 2021. Inhibition of esophageal cancer cell line (KYSE-30) proliferation using secondary metabolites of Ephedra endophyte bacteria. Nova Biologica Reperta 8: $95-$ 103. (In Persian).

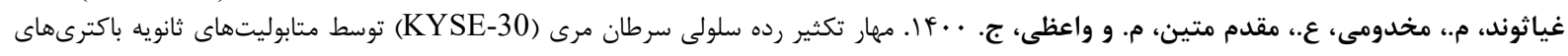

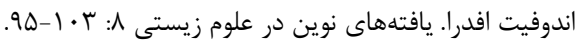

